\title{
As Cores de Pastore: reflexões fenomenológicas sobre o grafite e a arte de viver
}

\section{The Colours of Pastore: Phenomenological reflections about graffiti and the art of living}

\author{
Maíra Mendes Clini* \\ Universidade de São Paulo - USP, Instituto de Psicologia, Laboratório de Psicologia \\ da Arte. São Paulo, São Paulo, Brasil.
}

\begin{abstract}
RESUMO
Este artigo é baseado na Dissertação de Mestrado "As Cores de Pastore: grafite arte vida", tendo como alicerce e horizonte de pesquisa o método fenomenológico. É um trabalho em psicologia da arte, que tangencia as áreas da psicologia, das artes e da filosofia. Tem como objetivo compreender a vida e a obra de um grafiteiro-poeta. A partir do convívio com o artista Bruno Pastore foi possível constituirmos um mundo de acontecimentos, imagens e palavras. Revelamos sua trajetória de vida, trazendo à tona acontecimentos importantes e denúncias diversas. Elaboramos paralelamente leitura de suas principais produções artísticas, entre elas grafites e poesias. Concomitantemente, apresentamos ensaio filosófico baseado nas referências teóricas que essa pesquisa suscitou, inspirado principalmente em Martin Heidegger e seus comentadores. Neste artigo pinçaremos alguns aspectos pontuais da trajetória de vida de Bruno Pastore, bem como algumas amostras de sua obra, sob o fio condutor das reflexões filosóficas acerca da arte e do espaço.

Palavras-chave: Fenomenologia, Grafitos, Psicologia, Estética.
\end{abstract}

\section{ABSTRACT}

This work aims to understand in the light of phenomenology, life and work of a graffiti artist. From the meeting with the artist Bruno Pastore was possible for us to constitute a world of events, images and words, which resulted in the discovery of the meanings of art when built in life. Reveal, first, the trajectory of the artist's life, bringing up several key events and complaints. Then present his main artistic productions, including graffiti and poetry, always integrated with the context of his life story. Finally, we present a philosophical essay based on theoretical references that this study has raised.

Keywords: Phenomenology, Graffiti, Psychology, Esthetics.

\section{Introdução}

Poesia é a fundação da verdade. E fundar, aqui, se entende em dois sentidos diferentes: fundar 
como fundamentar, estabelecer alicerce, e fundar como começo.

Benedito Nunes

Este artigo é baseado na Dissertação de Mestrado "As Cores de Pastore: Grafite ${ }^{1}$ Arte Vida", defendido no departamento de Psicologia Social da Psicologia da USP em 2010. É um trabalho interdisciplinar em psicologia da arte, que tangencia as áreas da psicologia, das artes e da filosofia, tendo como alicerce e horizonte o método fenomenológico. Nesta abordagem, o processo de descoberta, como exercício da dúvida e abertura ao caminho, é mais valioso do que o seu produto final. No caso deste trabalho, o encontro entre pesquisador e depoente, e a relação que se construiu a partir disso é que ajudou a desvendar o sentido da experiência do artista como grafiteiro e as decorrências disso. Esse mergulho foi propiciado por uma série de encontros com Bruno Pastore, nos quais conversávamos longamente. $\mathrm{O}$ objetivo dessas conversas era deixar vir à tona como é o seu cotidiano e as influências que o contato com a arte nele produziu. Para ser coerente com o método escolhido, as entrevistas se pautaram em perguntas abertas. A própria conversa nos levou a rumos imprevisíveis de antemão, a nossa presença serviu como estímulo para que Bruno Pastore trouxesse à tona a sua verdade, e que sua vida e obra se desdobrassem diante de nós. O que definiu o momento em que os encontros puderam se encerrar foi a compreensão tecida por nós ao longo das horas e dos dias. Para nos aproximarmos ainda mais do mundo de Bruno Pastore, o acompanhamos na produção de um de seus grafites, e também fomos conduzidos pelo artista em uma de suas exposições. O levantamento das obras de Pastore foi realizado a partir de fotografia e também pela Internet, sempre com o consentimento expresso do artista. Ele possui sua obra publicada em sites e blogs, dos quais a indicação se encontra em anexo. O procedimento adotado nesses encontros propiciou a leitura de autores variados, em pesquisa que visava aprofundar os temas levantados nessa interlocução.

Neste artigo elegemos alguns pontos da rede de relações para apresentação, portanto pinçaremos alguns aspectos pontuais da trajetória de vida de Bruno Pastore, bem como algumas amostras de sua obra. ${ }^{2}$ O que nos conduziu, no presente ensaio, foram as reflexões acerca da arte inspiradas por Martin Heidegger.

\section{Sobre arte e espaço em Heidegger}

Martin Heidegger critica a tradição clássica e toda a história da filosofia ocidental, que se desenvolveu a partir do pensamento de Sócrates e Platão. O filósofo alemão nomeia o modo vigente de 
pensar de metafísica que se refere tradicionalmente à história do esquecimento do ser. Na metafísica, busca-se "fixar o ser como um ente entre outros" (CASANOVA, 2006, p.126), e aniquilar qualquer anúncio da negatividade. "A ciência nada quer saber do nada" afirma Heidegger em seu texto "Que é Metafísica" (1989, p.37) - e com essa postura a ciência tende a entificar todos os fenômenos, não considerando o ser que Ihes condiciona o modo de mostração. A metafísica também se revela como um pensamento marcado pelo dualismo e expresso sempre por dicotomias. Em Platão, uma das principais dicotomias é a diferença entre mundo das ideias e mundo sensível. Na modernidade, a dicotomia sujeito-objeto é sedimentada por Descartes. Ao conceber como separados sujeito e objeto, o mundo e tudo o que há nele passa a ser visto como disponível para o homem-sujeito, que se assegura a partir de sua subjetividade e passa a dispor desse mundo. Tal subjetividade moderna se fundamenta na "cisão insustentável entre a ordem espontânea das coisas e a ordem humana construída pela episteme filosófica e científica" (CAMPOS, 1982, p.16). Os pares matéria-forma e sujeitoobjeto marcaram todo o pensamento ocidental:

\begin{abstract}
A modernidade aparece associada, em Heidegger, não apenas à dominação tecnológica, mas também, colocando a questão de forma um tanto esquemática, à industrialização versus manualidade do trabalho na oficina, à cidade versus campo, à ameaça de perda da identidade de um povo versus seu enraizamento ao solo natal, à técnica versus arte. 0 niilismo contemporâneo trazido pelo domínio da tecnologia seria, para ele, o resultado inevitável do pensamento metafísico iniciado com Platão, que teria encontrado um de seus momentos mais expressivos no racionalismo iluminista, dominado pela matemática e pelas ciências naturais. (SARAMAGO, 2008, p. 65)
\end{abstract}

O sujeito moderno, prenhe de subjetividade, é aquele que pode manipular livremente os objetos ao seu redor, na tentativa de previsão e controle do que se manifesta. Essa postura, elevada a altíssimas potências, transforma o próprio homem em uma das variáveis a serem controladas, ou seja, em última instância, transforma tudo em objeto, inclusive todo e qualquer homem. Heidegger considera que esta é uma das características principais da era da técnica, que consiste na pretensa dominação e controle por parte do homem em relação às coisas e à natureza, na tentativa de eliminação de tudo o que é retração ou mistério. Em última instância, consiste numa tentativa de controle, previsão e manipulação de tudo o que está ao redor, inclusive de outros homens. Na era da técnica, o homem dicotômico, supostamente senhor de si por confiar plenamente em sua subjetividade e na objetividade do mundo que o rodeia, apodera-se de sua realidade, na tentativa de tornar-se o 
senhor do universo (BEIAINI, 1985, p.11). No pensamento de Heidegger, em cada época tudo se mostra a partir da mesma medida, então, na era da técnica, todo o espaço é dominado por ela. Na era da técnica a verdade passa a ser vista como adequação e corretude, conceitos esses que, desde Descartes, se baseiam na verdade como veracidade. Essa concepção de verdade faz-se nítida, por exemplo, no predomínio do cientificismo moderno, no qual tudo é passível de cálculo e previsibilidade. Na tentativa de resgatar aquilo que ficou perdido durante a vigência da metafísica, Heidegger retorna ao pensamento pré-socrático e estabelece um quadro crítico da noção vigente de verdade. "Essa essência da verdade que nos é corriqueira, a corretude da representação, levanta e cai com a verdade como não-encobrimento do ente" (HEIDEGGER, 2007, p. 36). Heidegger recorre à concepção de verdade dos gregos, na qual verdade é aletheia. Para Nunes, (1999, p. 79), a concepção de verdade metafísica, em Heidegger, é "desalojada de seu lugar proposicional e conceituada de acordo com a palavra grega a-letheia [nãoesquecimento] [a-lethes], desvelamento, não-ocultamento etc.," Conceber a verdade como aletheia retoma o mistério que existe em tudo o que se mostra, pois, sempre que algo que se mostra há também algo que se vela, o que torna qualquer fenômeno irredutível ao pensamento calculista e objetivador. Veremos a seguir a importância da arte para a compreensão da concepção da verdade em Heidegger.

A arte tem um lugar privilegiado no pensamento tardio de Heidegger, pois, segundo ele $(1964,2008$ e, p.21): “Mais filosófica que a ciência e mais rigorosa, ou seja, mais próxima da essência da coisa - é a arte". A reflexão proposta pelo autor pretende apontar e relembrar perguntas que ficaram esquecidas ao longo do tempo. "Heidegger não apenas pensa a obra de arte como manifestação da verdade como volta a pôr a arte em questão, o que implica assumir já não saber o que é arte, o que é a obra e qual a sua origem" (DUARTE, 2008, p. 24). Heidegger contesta a entrada da arte no horizonte da estética, pois, como nos esclarece Duarte (2008, p. 24), o filósofo quer deslocar o pensamento das "abordagens filosóficas que, desde que os finais do século XVIII, conceberam a arte como um domínio específico de produção, reflexão e fruição, o domínio estético, consolidado por Kant a partir de sua delimitação em relação aos campos teórico e prático". Segundo Casanova (2010, p. 166) se aproximar de uma obra de arte a partir de uma abordagem fenomenológica exige "o alijamento prévio de toda teoria e uma imersão existencial no horizonte mesmo em que a obra aparece". O por-se-em-obra da obra de arte evidencia como se dá a abertura do ente na totalidade, em meio a qual o homem ${ }^{3}$ sempre se encontra, ao mesmo tempo em que explicita a época do ser de maneira privilegiada, uma vez que a obra tem a potência de abrir mundo e de 
revelar mundo, como veremos a seguir. "O que Heidegger faz é colocar a obra de arte em relação com o horizonte de sua própria mostração" (CASANOVA, 2010, P.153. grifo do autor). A arte, para Heidegger, guarda em si o germe de um questionar mais fundamental, que pode nos tirar da névoa do esquecimento do ser e do obscurecimento da medida de nossa época. Assim, os caminhos da arte podem nos levar a lugares mais próximos da pergunta capital de todo pensamento heideggeriano, a saber, a pergunta pelo ser.

Tirar a arte do horizonte da estética seria trazê-la de volta para a esfera do indomável, do indescritível e do surpreendente. A estética à qual Heidegger se refere, por ser uma faceta da metafísica, exalta uma tendência a acreditar que o homem tem o poder de desvendar tudo, de esmerilhar as coisas existentes na tentativa de explicá-las e controlá-las. Entretanto, a obra de arte, para Heidegger, é algo que irrompe com toda a força, abrindo significados no mundo, e no mesmo instante se retrai de volta à terra, de onde misteriosamente surgiu. A essência da obra de arte é o pôr-se-em-obra da verdade. Para Heidegger, a arte tem um caráter paradigmático por ser uma expressão audível do tempo, e ser também espaço de temporalização do próprio tempo, constituindo assim um espaço privilegiado de acontecimento. Segundo Casanova (2010, p. 172) “[...] cada ente que se torna manifesto no interior da obra de arte é expressão direta do modo como seu mundo é fundado, da medida fática que torna possível a constituição de um ritmo cotidiano próprio".

No texto "A Origem da Obra de Arte", Heidegger cunha os conceitos de terra e mundo, e a obra de arte é o combate entre esses termos. Terra é para onde tudo se recolhe e de onde tudo surge, é inapreensível e sempre obscura. Mundo é a rede de significados, é abertura e clareira. Mundo, para Heidegger, não é apenas um local dentro do qual se mora, ou contorno preenchidos de limites e fronteiras geográficas. Segundo Casanova, "a concepção heideggeriana do assentamento originário do mundo sobre a terra representa uma alargamento substancial do modo como Heidegger pensava o mundo no interior de Ser e Tempo" (2010, p.169). Antes, mundo referia-se sempre a uma certa familiaridade, pois é rede referencial, trama de significações, e "se mostra como uma semântica fática sedimentada, que orienta todas as possibilidades de realização dos projetos existenciários cotidianos do ser-aí" (Casanova, 2010, p. 169). Nessa concepção, mundo não apresentava relação direta com a negatividade, algo que apenas o homem poderia experimentar. Após o texto "A Origem da Obra de Arte", mundo só existe se referido a terra, então, ele próprio carrega consigo o anúncio da negatividade. Nesse momento "as próprias semânticas agora pensadas como ontologias globalizantes dotadas de uma medida simples, encerram em si explicitamente essa instabilidade" (Casanova, 2010, p. 170). A seguir veremos como mundo e terra se 
relacionam tensamente num combate entre ambos, a partir das reflexões sobre a obra de arte.

A obra de arte é o lugar onde o combate entre terra e mundo fica evidente e nunca se extingue, mantendo-se tenso, e assim trazendo à tona o que há de mistério na terra enquanto misterioso, e o que há de claro no mundo, enquanto aquele que constrói significados. É na obra que se mostra o indecifrável da terra e o explícito do mundo, sem que nunca um dos combatentes sucumba ao adversário.

A terra, que se mantém imperscrutável, difere da terra como material orgânico. Segundo Figueiredo (1994, p.96) "a terra é ao modo do que se reserva e resiste: o som, enquanto som, é impenetrável; a palavra na sua plena eficácia não se abre para um desvendamento analítico; as cores quando chegam a ser completamente cores retraem-se e fecham-se sobre si mesmas". Na obra de arte, a matéria vem à frente na sua especificidade, mais do que em qualquer outro uso que se possa fazer dela. Segundo Casanova (2010, p. 163) "Diante de uma obra de arte, vemos que ela sempre traz à tona de modo radicalmente expresso a multiplicidade de elementos que é a dela".

Não é o homem que faz uso da matéria para produzir a obra de arte, mas sim, a obra acontece através do homem que a cria. "O artista é aquele que se deixa antes apropriar pela história para que essa história mesma fale no interior da obra." (CASANOVA, 2010, p. 174). O pôr-se-em-obra da verdade na obra de arte elimina qualquer caráter subjetivista acerca da criação da obra ou da sua execução. "A obra não é apenas trabalho do artista, mas é muito mais horizonte de realização da verdade" (CASANOVA, 2010, p. 176). O artista não usa a matéria ou desgasta-a, é apenas o canal para que venha à tona um mundo através da manifestação e do recolhimento daquela matéria, e assim o que ela tem de mais específico venha à frente. Qualquer tentativa de destrinchar a terra está fadada ao fracasso. Podemos perceber nitidamente esse fracassar no exemplo descrito abaixo por Heidegger, no qual a tentativa de encontrar a pedridade da pedra acaba por destruí-la, sem mesmo chegar a qualquer resposta, senão fragmentos, corretos e comprováveis, certamente, mas apenas fragmentos dissociados:

Mas por que é que esse elaborar da terra tem de acontecer de tal forma que a obra se recolha nela? O que é a terra, para que chegue ao não-encoberto precisamente dessa maneira? A pedra pesa e carrega sua gravidade. Mas enquanto esta pesa sobre nós, nega-se ao mesmo tempo a toda penetração nela mesma. Tentemos algo assim, destroçando a rocha: ela nunca mostrará em seus pedaços um interior e aberto. Na mesma hora, a pedra se recolheu de novo no mesmo abafamento do duro e maciço de seus pedaços. Tentemos atingir isso por outra via, pondo a pedra 
sobre a balança, e apenas traremos a gravidade para a contagem de um peso. Essa determinação talvez muito precisa da pedra permanece uma conta, mas o pesar se furtou a nós. A cor ilumina e também só quer iluminar. Se a medimos racionalmente, decompondo-a em freqüências, ela se ausenta. Ela só se mostra se permanecer não desencoberta e não esclarecida. A terra faz assim despedaçar-se contra si cada intromissão nela mesma. Deixa cada importunamento meramente calculista converter-se em uma destruição. (HEIDEGGER, 1936/2007, p.32)

A impotência do querer descrita acima por Heidegger explicita esforços em vão de encontrar o que é mais próprio da matéria através de medições calculistas. O autor chama nossa atenção para o fato de que a força da matéria está, justamente, ali onde ela não pode ser apreendida, explorada ou dominada. As operações técnicocientíficas, que medem, pesam, racionalizam, decompõem e analisam, conseguem apenas conclusões acerca do objeto sobre os quais se debruçam, ignorando a verdade que brota e ao mesmo tempo se vela nos fenômenos, sejam eles pedra, cor, obra ou ser humano.

É por isso que uma obra nunca pode ser desvendada por completo. A obra de arte guarda em si essa tensão entre mundo e terra, ou seja, explicita tanto o que se mostra quanto o que se esconde nela mesma. Vale ressaltar que o mistério que a obra guarda não pertence à sua "interioridade", pois tal mistério é o mesmo que se espalha pelos interstícios do mundo que habitamos. A obra, porém, tem o privilégio de trazê-lo à tona com mais prontidão do que os outros entes que nos rodeiam. Heidegger (1936/2007, p.51) afirma que, ao perguntarmos sobre definições a respeito da obra, já estamos impedindo a obra de ser obra, pois perguntamos a partir de nós mesmos: "a partir de nós que, por aí, não deixamos a obra ser obra, mas antes a representamos como um objeto que deveria causar em nós algum estado qualquer".

Como nos lembra Duarte (2008, p.28), criar e resguardar a obra existem em função da obra, e não em função do homem e de seus sentimentos e comportamentos. Resguardar a obra não significa apenas garantir as condições climáticas e físicas para que ela não se desgaste, tampouco significa exibí-la num museu, galeria, praça pública ou parede. O fundamento do preservar a obra é saber, e sobretudo querer, resguardar a perturbadora verdade que ela abre no cotidiano. "No resguardar, a obra nos insere na abertura do ente e faz sair daquilo que é habitual. Um abalo silencioso nos remove e modifica as conexões habituais com o mundo e com a terra" (JARDIM, 2007, P.07). No caso do grafite, poderíamos pensar que resguardá-lo implica em trazer à tona a relação dos homens entre si e com sua cidade. Ser um guardião da obra implica na compreensão 
de que não somos nós que possuímos as obras, por mais que possamos adquiri-las, comprando-as e pendurando-as em nossa paredes, ou acumulando-as em nossas estantes, ou mesmo gravando-as incansavelmente em nossas mídias. O desafio proposto por Heidegger é o de que percebamos que, ao invés de sermos nós a manipular a poesia, é esta que deve sobrepor-se a nós, "de forma a que o nosso ser-aí se torne o suporte vital do poder da poesia". (HEIDEGGER, 2004, p.28)

Para termos acesso à verdade que se põe em obra na obra de arte, é necessário uma disponibilidade diferente daquela que prepondera no cotidiano. Heidegger afirma que, ao estarmos imersos na trivialidade da vida corriqueira, afastamo-nos da esfera de poder da arte, e esse afastamento depende menos da obra de arte do que de nós próprios. O poema, assim como toda obra de arte, abre em torno de si um mundo de significados e sustenta algo sempre velado. Segundo o autor, a luta pelo acesso à poesia é a luta contra nós próprios, e é justamente esse o trabalho de travessia do poema:

\begin{abstract}
Mas só tal como o próprio poeta se torna o senhor e servo da poesia, a saber, por uma luta, é que ganhamos, para além do poema existente, o espaço da poesia. A luta pela poesia no poema é a luta contra nós próprios, na medida em que, na trivialidade quotidiana do ser-aí, estamos expulsos da poesia, estamos sentados na praia cegos, coxos e surdos, e não vemos nem ouvimos nem sentimos a ondulação do mar. No entanto, a luta contra nós próprios não significa de modo algum um olhar absorto sobre nós próprios, curioso e analisador da alma, nem uma repreensão moral contrita, antes tal luta contra nós é o trabalho de travessia do poema. (HEIDEGGER, 2004, p.30)
\end{abstract}

O poeta-artista, ao carregar o fardo e a benção de ser capaz de cantar a poesia que nos resta, integra ao seu cotidiano o que está além e aquém do ordinário. $O$ artista se dispõe ao acontecimento histórico, reencontrando o tempo histórico no interior da obra de arte. Ele é o mensageiro da fenda, aquele que transita entre a clareza do mundo instituído e mediano, e as agruras insondáveis e obscuras da terra. "Em tudo com que aparece e se mostra familiar, o poeta faz apelo ao estranho enquanto aquilo a que se destina o que é desconhecido de maneira a continuar sendo o que é - desconhecido" (HEIDEGGER, 2008d, p.177). Ele tem a missão de resgatar o que de sagrado existe no seio do comum. Sagrado, para o nosso enfoque, quer dizer manifestação do mistério enquanto misterioso, que Haar chama de presença intacta. Sagrado é a impossibilidade de reduzir a terra ao mundo, de eliminar o mistério de uma vez por todas. Vejamos como ele descreve a missão dos poetas: 
A angústia reina porque o sagrado, condição de toda presença intacta, inclusive a de um deus, se retira, se apaga. Mas os poetas, Hölderlin ou Rilke, ao cantarem essa angústia podem ajudar-nos a suportar esta insuportável indigência e a atravessar esta "noite do mundo" que é o dia tecnológico. A técnica dessacraliza, porque ela detesta o que não pode ser dominado e finalmente o nega. Esta impossibilidade de domínio, de uma manipulação que ela não consegue realizar, quer se trate de sofrimento, quer de alegria, do amor ou da morte, só o canto poético consegue expressar, e talvez preservar (Haar, 2007, p.96).

As obras são lugares para os lugares: as obras não apenas ocupam um lugar, pois são também lugares em si, abrem ao redor de si e a partir de si mesmas toda uma região de encontro. São centros gravitacionais que constelam as relações humanas no modo mais profundo e fundante que poderíamos pensar: o homem em seu sercom-os-outros homens, e o homem e as coisas que o rodeiam, o homem e os utensílios por ele criados, o homem e o mistério, terra e mundo. "Ao dizermos espacialidade [...] notamos que se trata de algo indissociável de referência, ou relação (Beziehung). Espacialidade em sentido originário diz o lugar, como o mundo, em que se abrem relações"

(MOONSGURGER, 2008,

As meditações sobre a relação do homem com o espaço levaram Heidegger a tecer considerações sobre a escultura. Segundo Saramago (2008, p. 64) Heidegger faz uma contraposição entre "uma fenomenologia do espaço - aberto pela escultura, no caso -, e, por outro lado, uma abordagem técnica, teórica e representacional do mesmo, que o autor associava ao cientificismo moderno". Em seu fundamento, espaço é acontecimento. O termo região de encontro é uma das traduções possíveis da palavra alemã Gegende, que contém em si a idéia de encontro e de ir contra, ou seja, refere-se ao confronto que existe em todo encontro. Tal conceito é decisivo para compreendermos a visão de Heidegger sobre o espaço:

\footnotetext{
Heidegger compreende a região de encontro, a partir do alemânico Gegnen-de, como aquilo que vem ao encontro (das Entgegenkommende): não como algo individual que vem ao nosso encontro, e sim como a dimensão ou o domínio (Bereich) aberto a partir do qual e no qual algo pode mostrar-se, ou seja, pode surgir (hervorkommen) porque encontra um lugar nessa região e assim nos diz respeito (GUZZONI, 2008, p.53).
}

O espaço espaça, afirma Heidegger, e isso quer dizer que ele sustenta em si e ao redor de si as relações que acontecem no modo do habitar humano. O lar do homem é a máxima da habitação humana, é para onde o homem sempre pode retornar, mas de onde ele constantemente se distancia. Habitar não é simplesmente ocupar 
espaços. A arte de habitar é algo que tem ficado cada vez mais distante do cotidiano do homem, pois este está cada vez mais distante de sua origem. Para Heidegger, só é possível habitar propriamente a terra através da poesia. Sem poesia não existe habitação. Mesmo onde ela falta, ainda assim, a poesia é a referência primordial:

Um habitar só pode ser sem poesia porque, em sua essência, o habitar é poético. Um homem só pode ser cego porque, em sua essência, permanece um ser capaz de visão. Um pedaço de madeira nunca pode ficar cego. Se, no entanto, o homem fica cego, então sempre ainda se pode colocar a pergunta se a cegueira provém de uma falta e perda ou se consiste num excesso e abundância desmedida. [...] É possível que nosso habitar sem poesia, que nossa incapacidade de tomar uma medida provenha da estranha desmedida que abusa das contagens e medições. (HEIDEGGER, 2008d, p.179).

À arte resta a função restauradora de lembrar-nos que precisamos habitar a terra ao invés de usufruir desta. Ao grafite cabe a função inquisidora de ajudar-nos a resgatar a relação genuína com os espaços públicos, e reinventarmos uma ética do habitar na atual cidade. No limite, não existe cisão entre arte e vida, pois "o poético é realizável na própria vida." (NUNES, 2007, p.149). Assim como o "espaçamento é libertação de lugares" (HEIDEGGER, 1969/2009), habitar, de fato, é a libertação humana.

\section{A cidade, através dos grafites de Pastore}

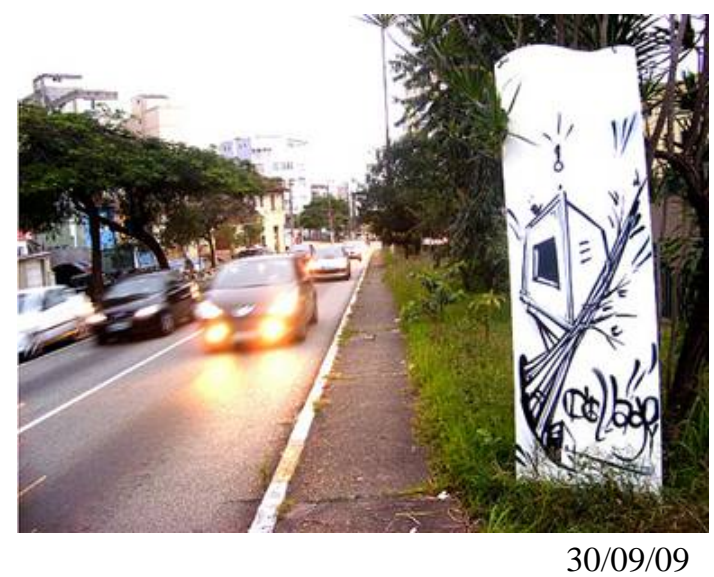

Uma espécie de post-it na Av. Heitor Penteado. A pintura ainda se encontra no local, interagindo com o cotidiano público, pois a arte é um lugar de encontros, potencial para transformar o espaço social e as relações humanas.

Cidade de São Paulo. Maior metrópole brasileira. Cidade construída e dedicada ao trabalho. Andando por suas ruas, percebemos uma cidade multifacetada, estrangeira, caipira, imigrante e migrante. Somos italianos, portugueses, espanhóis, chineses, africanos, nordestinos, paulistas. Somos centro e periferia, miséria e luxo, capitalismo, consumo e fome. Somos propaganda e vendas, produção 
e consumo. Somos ilhados e conectados. Somos paulistanos.

A cidade é concreto, com algumas poucas ilhas de verde e natureza. A cidade é deserto de cimento, com oásis efervescentes de arte e colorido. A pressa predomina, e o movimento de reter-se na pausa é raro, porém, imprescindível: é ele que garante algum respiro à cidade. Sua transpiração libera ações criativas que exalam por entre seus poros poeirentos. Na inspiração a cidade se nutre daquilo que ela também não é. No contexto hostil e voraz da cidade, que num gole nos devora, encontramos a possibilidade de nos embebermos do seu contrário. Produtividade e aquisição podem, por um segundo, perder o sentido. Ao contrário, do avesso, contrastando, o oposto se enquadra e se libera, se adéqua e novamente incomoda. Esse é o movimento do grafite. Os quadros de cores e letras têm como moldura e suporte os muros que somos nós, imbricam-se em nosso cotidiano à revelia de nossas exigências e preconceitos. Se letras teimosas e rebeldes insistem em aparecer em nossas fachadas, estampando em nossas caras símbolos de impossível compreensão, se personagens coloridos arrebentam nos muros alhures de nossa estada, se de repente já não sabemos muito bem o que é paisagem ou passagem: assim irrompe o gesto que vira arte que vira produto que vira consumo que vira nada que vira algo de novo. Viramos-lhes as costas e eis que a imagem surge de dentro de nossa pálpebra a nos rememorar tudo aquilo que não queríamos ter visto. Já não sabemos como classificar os grafites que teimam em aparecer e desaparecer.

O grafite é oriundo da cultura Hip Hop, que surgiu nos guetos de Nova Iorque, nos Estados Unidos, na década de 1970, e teve como berço o bairro do Bronx, cuja população era predominantemente negra. Silva e Silva esclarecem:

\begin{abstract}
Através de uma expressão gráfica transgressora constituída pelo grafite, de um estilo musical inovador quanto à proposta rítmica e melódica como o rap, e de um modo de dançar igualmente original, cujos movimentos interpretam a descontinuidade e a velocidade dos beats repetitivos produzidos pelo disque jóquei que é o break, o Hip Hop abrange diversas manifestações artísticas que se popularizaram como "arte de rua". Os primeiros protagonistas deste movimento foram, na sua maioria, jovens, negros ou descendentes hispânicos, moradores dos bairros periféricos de Nova Iorque (SILVA; SILVA, 2008, p. 136).
\end{abstract}

O movimento Hip Hop surge como contestação e transgressão contra a hegemonia branca. Scandiucci (2006, p. 226) afirma que esse movimento chegou ao Brasil na década de 1980, época de redemocratização, que, a partir do milagre militar, teve como uma das conseqüências o aumento da população pobre do país, em 
virtude da decorrente crise econômica. O movimento Hip Hop se manifesta, principalmente, em comunidades que moram nas periferias da cidade, ou em partes marginalizadas de grandes centros urbanos. Hoje em dia ele não se restringe apenas a questões de raça, mas pode ser o porta-voz de insatisfações e contestações. Do mesmo modo como pode ser uma ferramenta de conscientização e engajamento político, o Hip Hop também acabou sendo englobado pelo mercado, assim tornando-se um produto de consumo. Não é nosso objetivo aprofundarmo-nos sobre o movimento Hip Hop, cabe apenas salientar que, atualmente, ele guarda essa ambigüidade entre subversão e contestação de um lado, e adequação às leis do mercado cultural de outro.

Quando falamos em movimento Hip Hop, nada mais justo do que validarmos a voz de um grafiteiro para darmos continuidade às nossas reflexões. Para Bruno Pastore, grafite é qualquer risco em uma superfície. Rabiscos em geral: nas paredes, em papéis, em móveis diversos, nas coisas. Desde muito cedo, Bruno experimentava as possibilidades dos riscos nas superfícies. Bruno Pastore, em entrevista, relata que o Hip Hop é uma porta de entrada para quem está fora, e uma porta de saída para quem está dentro. O grafite é um meio de alçar voo para muitos grafiteiros como ele:

\begin{abstract}
O Hip Hop é uma porta de entrada para quem está fora, e ele é uma porta de entrada para quem está fora das coisas, para ser inserido, como inclusão, como grito, como auto-estima, ele é uma porta de entrada para quem está fora. E ele também é uma porta de saída para quem está dentro. Porque, do Hip Hop, você pode, você deve buscar outras coisas. [...] O rap é bom quando ele voa, quando ele migra do rap, vai buscar referências em outros lugares. Então, o Hip Hop por ele só ele não se sustenta, ele não é... Ele é o que? Ele é uma ideologia. Para mim, ele é isso daí, ele é uma porta de entrada para voar. Ele é que nem um pássaro, e se ele não voa, não existe.(Pastore, 2010)
\end{abstract}

Bruno Pastore nasceu em Guarulhos, dia 09 de Novembro de 1985. Sua filiação já aponta para traços distintivos de seu percurso. Filho de pai não reconhecido, Bruno foi criado pela mãe, Maria Izilda, e pela avó, Adail. Ao longo de sua trajetória, ele transitou por diferentes espaços e regiões: nasceu em Guarulhos, passou boa parte da adolescência no bairro do Belém, morou menos de dois anos no bairro de Sumaré, e retornou recentemente para Guarulhos. Cresceu assistindo sua avó costurar e fazer doces, e assim, desde cedo, habituou-se a artesania. Sua avó é sua primeira referência artística. Desde pequeno Bruno se impressionava com as linhas, as formas, as cores e texturas das coisas que o rodeavam.

A vida de Bruno está marcada, desde o início, pelo risco de consumar-se em um Zé Ninguém. Mas ele tem vontade de crescer, 
de expandir os horizontes, luta com todas as suas forças por tornarse alguém. Ser alguém. O risco que se apresenta como ameaça torna-se parceiro e abre possibilidades de caminhos. Bruno nos apresentou diversos aspectos desiguais que encontrou em sua vida. Gostaria de ressaltar, porém, que esses fatos não são acontecimentos subjetivos individuais. São amostras, isso sim, de um fenômeno mais amplo e complexo, ancestral, como diria Gonçalves Filho (2007, p. 187). A desigualdade fica evidente na divisão da cidade, que pode ser sutil ou explícita. Para Estrella (2006, p.14), a batalha cotidiana do grafite se expressa numa espécie de cruzada visual para lembrar à cidade a sua humanidade. Humanidade essa que, na maior parte das vezes, "escolhe" onde pousar, pois não acontece de forma igualitária em todas as regiões. Segundo Gonçalves Filho (2007, p.200), "os espaços e caminhos públicos, na sociedade de classes, são imantados pelo poder de segregar, pelo poder de sempre atualizar a desigualdade".

Muitas vezes, a humanidade fica esquecida na aridez das periferias das grandes metrópoles, regiões privadas de recursos e de investimentos públicos. O mundo instalado e erigido pelos grafites, muitas vezes, refere-se à exarcebação da degradação e precariedade urbanas. Ao levantar um mundo de cores em meio ao cinza do concreto, ao levar para lugares de passagem e pressa personagens, tags, movimentos de outros ritmos, salienta-se o ambiente que os acolhe e envolve. Componentes citadinos, tais como sujeira, poluição, muros desmantelados, calçadas esburacadas, bueiros e afins, são parte integrante das obras que nos lembram de que há tudo isso na cidade, mas que também há algo de outro. Nem sempre os grafites são erigidos em lugares degradados ou desagradáveis, mas sempre se relacionam com uma abertura para algo de outro na cidade, algo que abre as portas do estranhamento e da reflexão. $O$ apelo dos grafites é para que se quebre o automatismo e a alienação corriqueiros, mas esse apelo pode ser ouvido ou não.

A seguir, apresentaremos uma série gráfica de Bruno Pastore, cujo tema principal são monstros. Etimologicamente, a palavra monstro deriva do latin: mostrare, que significa mostrar, tornar evidente. Portanto, monstro é aquele que torna evidente algo excepcional, que chama a atenção por se diferenciar do que é considerado normal. Nestes trabalhos monstruosos, percebemos com freqüência referências a doença, protesto, desamparo, revolta. Cinzas, negros, roxos, e até vermelhos alternam-se entre figura e fundo, cruzam-se ao serem flagrados por um olhar que com eles se identifica, se desaloja, decifra e a eles sucumbe.

Nos dois trabalhos seguintes, esses temas ficam evidentes, não apenas nos traços e cores, mas principalmente chamam a atenção pela metalinguagem que Pastore usa ao descrever a técnica utilizada para a produção dos trabalhos. Pastore brinca com o detalhamento 
do modo de fazer, com a descrição do suporte e dos materiais utilizados, explicitando, nessa metalinguagem, o elemento preponderante nas obras:

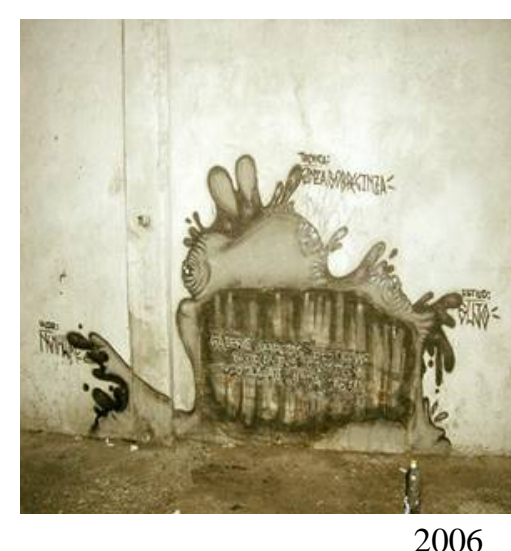

Intervenção-urbana Mooca [...]

Técnica: Cinza sobre cinza

Estilo: sujo

Valor: nenhum

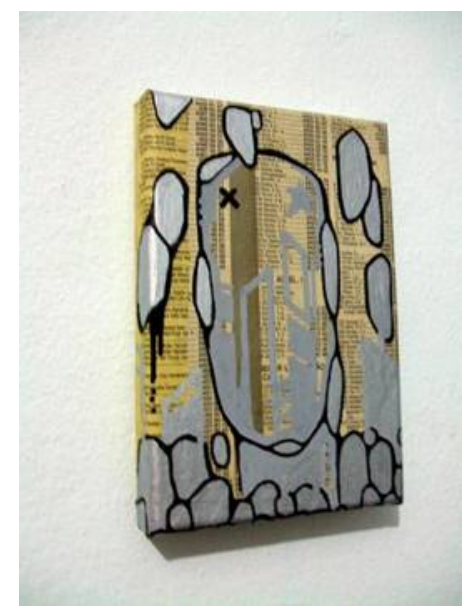

colagem e caneta posca sobre tela, tela sobre dias ruins.

$14 / 11 / 07$

Os monstros de Pastore chegam a ser assustadores e nos levam a lugares difíceis de visitar. A seguir, o filho primogênito dos monstros de Pastore: 


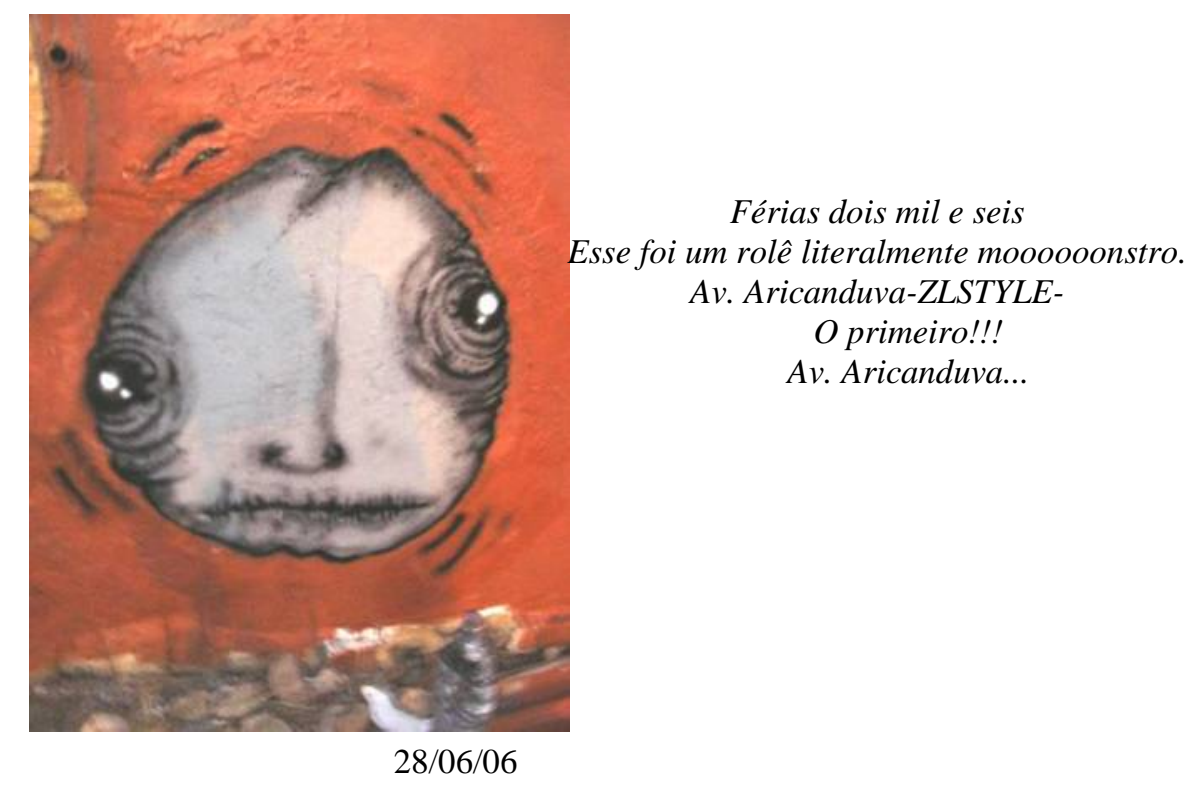

O monstro pode evidenciar a doença que está à solta; pode mostrar que, através do grafite, aparece o que transborda de dentro do coração e que se difunde cidade afora; pode explicitar o contraste entre uma intervenção urbana e a realidade social. O monstro demonstra a indignação frente a processos impostos pela sociedade e pelos governos, devolve na mesma moeda o cinza soberano oriundo das camadas de tinta derramadas pelo poder. Quando são muitos, envolvem a vida e rodeiam as idéias. No limite, são remédio contra a profecia de nascer e viver na iminência de ser um Zé Ninguém. Quando tristes, os monstros ressentem-se pelo que acontece ao seu redor; quando bravos, eles se vingam do que não puderam escolher. Estampar o monstro no muro é forçar um diálogo do oprimido com sua cidade, é gritar contra a profecia - aparentemente - autorealizável de engolir a sujeira cinza da metrópole e ser soterrado por ela.

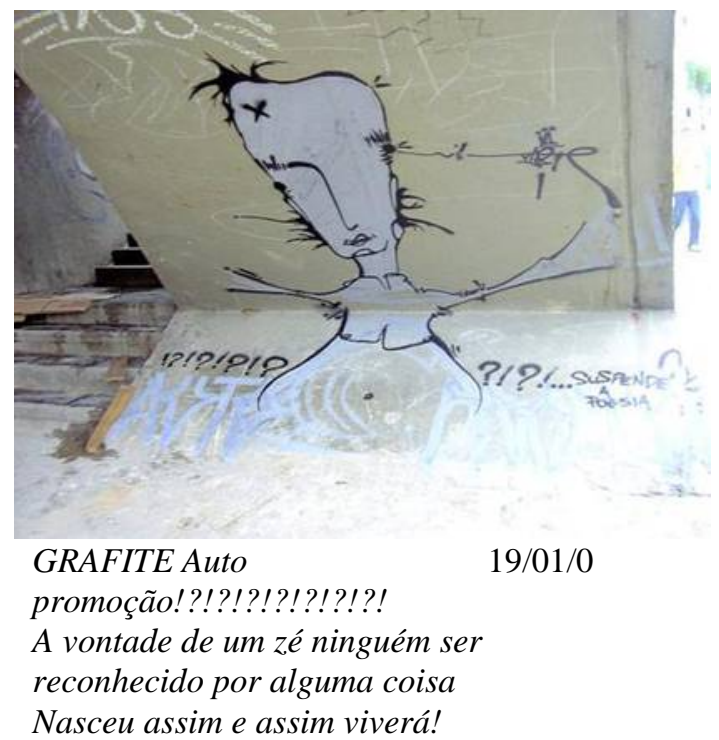


Maíra Mendes Clini

As Cores de Pastore: reflexões fenomenológicas sobre o grafite e a arte de viver

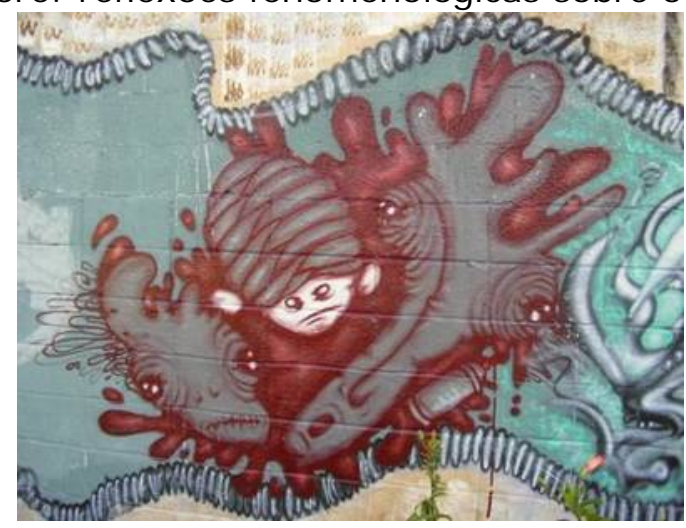

São vários ao meu redor!!!

$12 / 09 / 06$

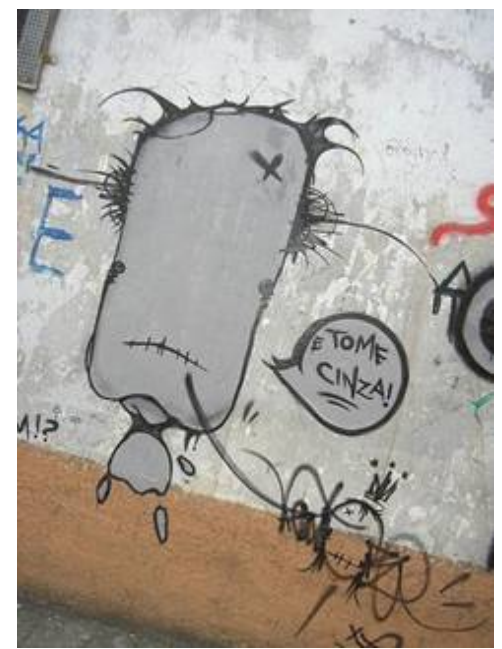

27/06/07

E tome cinza! Há Bresser

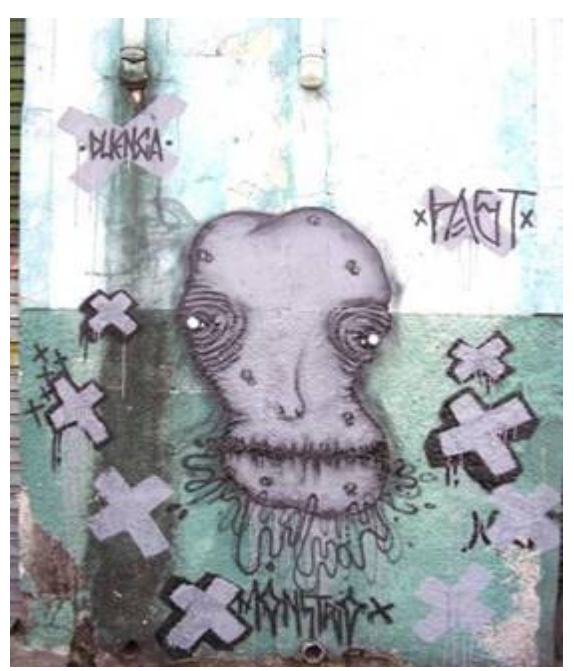

xXDuençaXx

17/07/06

Cuidado com o monstro!!!

a doença esta a solta. 


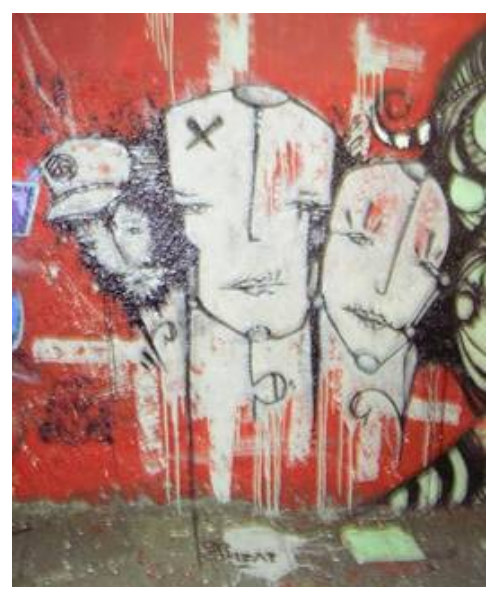

Pompéia-2007desculpe pelo cinza, mas me obrigam! só o começo...

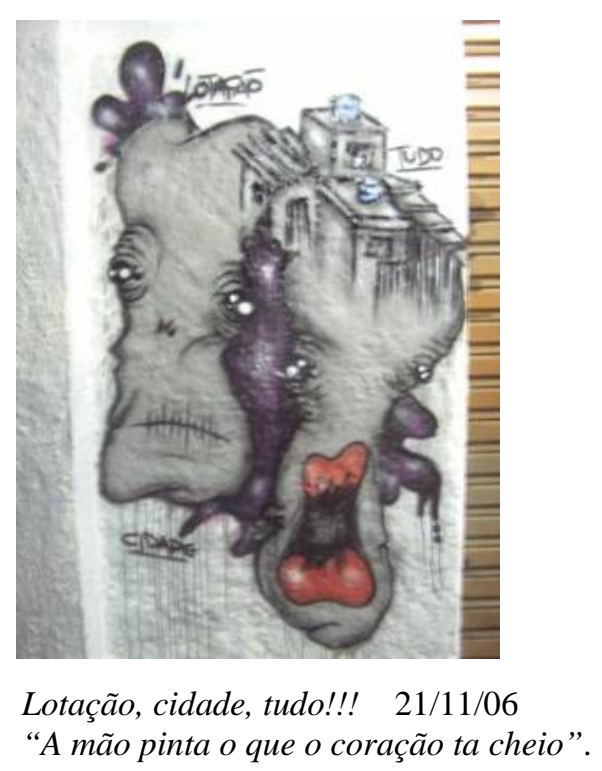

As obras de arte têm a força de trazer à tona a temporalidade que pode ficar esquecida no modo automatizado e mediano da vida cotidiana. São como arautos que atravessam todos os tempos e nos lembram de que a duração está inscrita nas coisas, e que o homem tem o tempo como estofo do seu corpo. Os grafites trazem consigo e erigem toda a fugacidade da época atual. É preciso pressa na sua execução, pois a cidade interpela o artista o tempo todo; é preciso ser hábil para brotar no seio da cidade, correndo risco de desaparecer instantaneamente; é preciso haver algum movimento de conservação para que os grafites perseverem apesar de tudo isso, e ainda assim possam ser comercializados.

O grafite, quando eclode nas ruas, é gesto, é primitivo, é espontâneo, é efêmero e caduco. Pode sumir por completo no segundo seguinte de sua origem. Vivemos, porém, numa época que exige a perpetuação em termos materiais e simbólicos, exige que o signo 
seja transformado em mercadoria para que assim possa ser consumido. O paradoxo instala-se: se à arte é permitida alguma efeméride, o fluxo da mercadoria demanda que o simbólico torne-se palpável, para assim poder ser comercializado. O grafite também busca passear pelas galerias, precisa se transformar em algo que dure, seja através das fotos que os perseveram nas mídias on line, seja na decoração de interiores e exteriores que pode gerar rendimentos, seja no mercado de arte que tem a sua exaltação no mundo das galerias.

Para Bruno, apesar do grafite ter a ver com grupos, gangues e galeras, na realidade é uma arte de ninguém, pois o lugar do artista grafiteiro pode ser perene e instável, e muitos estão fadados a viver no anonimato. A rua é desapego e desamparo, e o grafite é uma arte efêmera, que pode sumir no instante seguinte de sua criação. Aqui entramos num ponto crucial: o grafite é uma efeméride, e os grafiteiros procuram a perpetuação. Querem ser alguém que possua passado, presente e futuro, e querem se apropriar dessa duração. Para perseverar através do tempo, é preciso passear por galerias de arte, e passar dos muros para as telas. A pintura aguça a idéia de eternidade e, paradoxalmente, aponta para a finitude do artista. O grafite explicita ainda mais essa finitude, por ele mesmo já ter seu fim marcado desde o primeiro traço.

Uma das maneiras de perseverar na cidade é espalhando sua assinatura por aí, assim se pode transformar um lugar de ninguém em território. Território quer dizer região, nação. Já não falamos mais de aspectos geográficos, falamos de espaços habitados. Espalhar-se pela cidade possibilita dominá-la como pertencimento e ocupação. As tags, assinaturas dos grafiteiros, são hieróglifos de significados compreendidos apenas por quem participa da escrita. Dominar um código que não é reconhecido por qualquer um pode garantir o sentimento de exclusividade àqueles que constantemente se sentem excluídos. Se faz presente no conjunto, no qual cada um marca seu nome ou sua tribo, sua gangue. Pertencer a uma gangue é pertencer a um coletivo, espalhar sua tag pela cidade é espalhar assinaturas, é marcar seu nome, tomar existência na cidade. Ela guarda consigo mais do que um nome, guarda um mistério, aponta para algo que não é apreensível num primeiro momento. Ela exala sua fundação, contém em si o grupo ao qual pertence. Ao marcar sua Tag, o grafiteiro representa toda uma coletividade.

A seguir temos uma série de trabalhos feitos em conjunto, nascidos na espontaneidade dos roles (passeios) pelas ruas, nos quais Pastore participou com seus traços e cores. Vale à pena atentar para o modo como os traços característicos de cada artista se articulam e se ligam, se embaralham e se diferenciam. Poderemos observar qual a maneira de Pastore, junto a parceiros diferentes. 
Maíra Mendes Clini

As Cores de Pastore: reflexões fenomenológicas sobre o grafite e a arte de viver

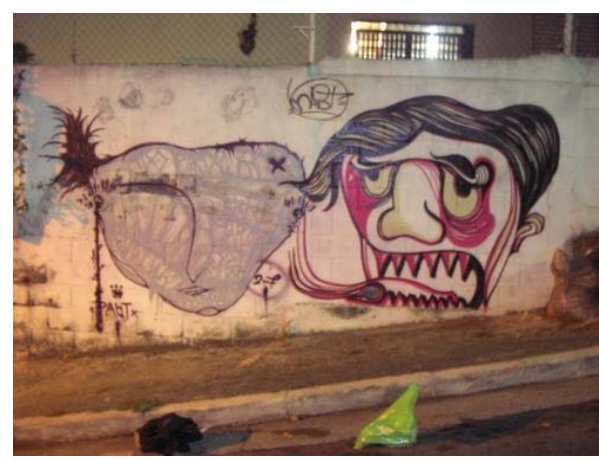

rolê la pela VM.

$27 / 04 / 07$

tá aí, meio cinza mas estamos aí.

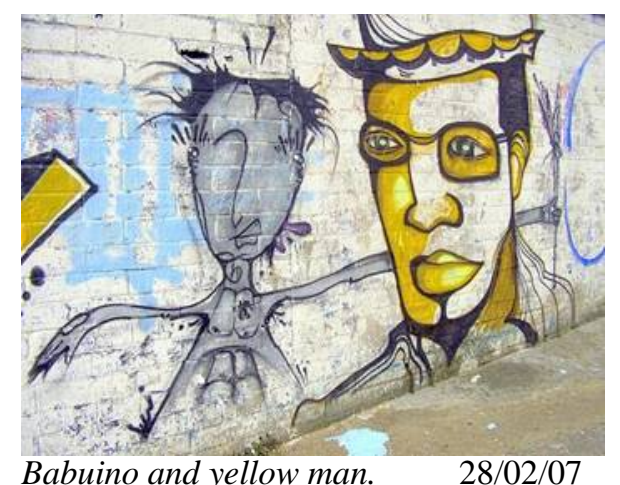

Babuino and yellow man.

28/02/07

Av. Sumaré VIBE!

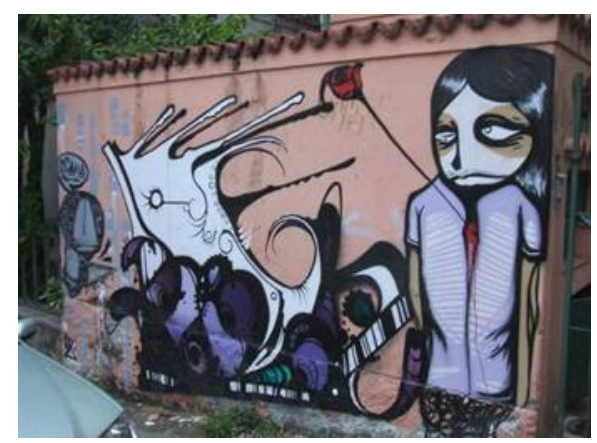

noix! [...].

$28 / 08 / 07$

Carrão style, loko o role meio conturbado mas do jeito que nóix gosta. entranhadamente, integração, sinta a verdadeira vibe, além da tinta.[...] ro ronovação é necessária!

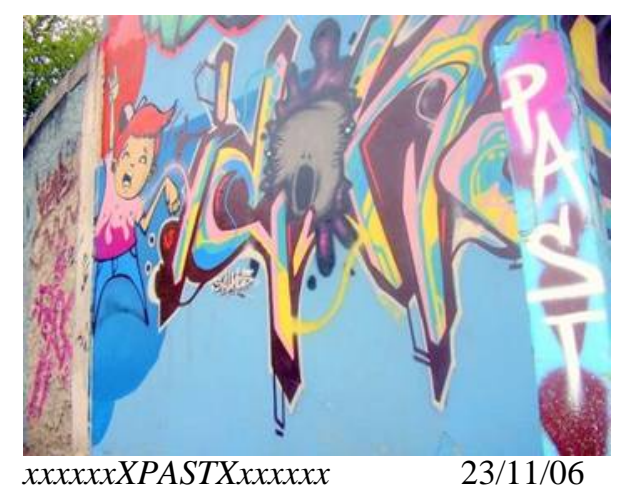

rolê na vila do gelo, firmeza ó

valeu!!!2@@6ono do monstro.

-Sarajevo. stencyl sobre sulfite, eletrogravura e sentimento do coração. 


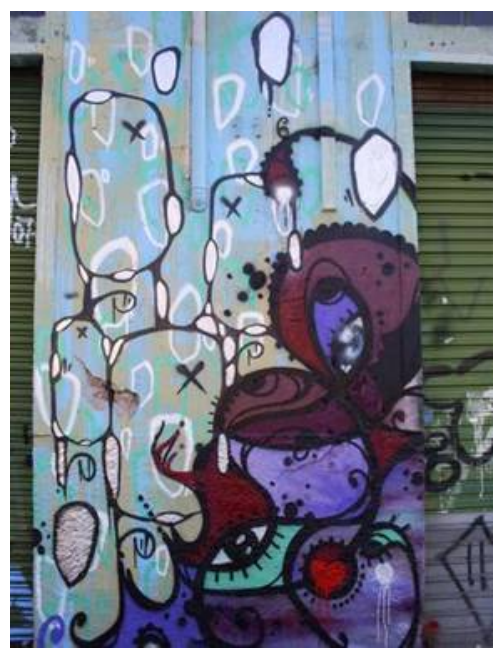

Ei!!! ainda estou pintando heim, [...]. É, aquela vibe...[...]VALEU!!! blessed!!!2@@7thank’s jah! NÓIX!!!

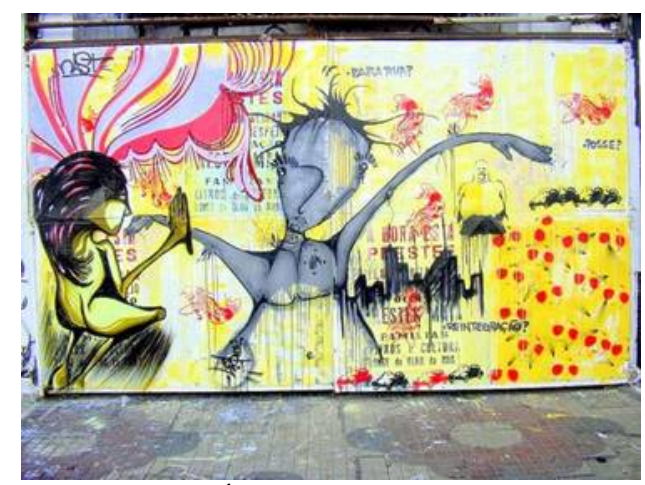

A HORA ESTÁ PRESTES 22/02/07

pela hospitalidade e contra o despejo da ocopação "Prestes Maia" Famílias Livros e cultura. Lonie do olho da rua!

Os grafites desvelam e fundam o modo como nos relacionamos com a cidade atualmente. Eles descobrem novos modos da arte acontecer, revelam também os jogos de poder institucionais reinantes e as leis de mercado, ao mesmo tempo em que contestam tudo o que foi dito acima. A cidade é o berço do grafite, é onde ele surge, e para onde invariavelmente retorna, independentemente dos outros espaços por onde possa ter circulado.

Retomando o que afirmamos acima, a obra de arte explicita o mundo ao qual pertence, ou seja, é um aceno do modo como a sociedade que a abriga acontece. O grafite é parte integrante deste mundo que o sustenta, assim como é fração da face do povo que o cria e guarda. O grafite, no seu movimento de passear entre muros e galerias, explicita, de um lado, a necessidade de eclosão de movimentos juvenis criativos e subversivos, e, de outro, uma forte tendência mercadológica da sociedade. No mesmo instante em que grandes grafiteiros ganham milhões com obras encomendadas para peças publicitárias, outros grafiteiros mirins descobrem-se capazes através da potência das suas jovens tintas. 
Pastore experimentou a força do contato com a arte, e deixou com que a arte se tornasse o sentido para sua vida. Como jovem nascido na periferia, ele atravessou inúmeras experiências de abandono, exclusão, humilhação e falta de perspectiva. Durante a aventura explosiva de sua adolescência, transitou pelo mundo das drogas, pelo confronto com a polícia, chegando inclusive a ser preso mais de uma vez. A produção de arte através do grafite e da poesia sempre o acompanhou como égide e alvitre, e ele acabou fazendo a opção de se lançar no mundo da arte, deixando de lado outras oportunidades que Ihe apareceram, mas que não faziam sentido dentro do seu projeto de vida, como fazer carreira numa multinacional, por exemplo. Atualmente Bruno Pastore trabalha como arte-educador, compartilhando com outros jovens tudo o que seu percurso the ensinou.

Para Pastore desenho é desígnio, é o modo como ele atende o chamado para a vida. Um dos desígnios que perseguiu Pastore e foi por ele perseguido diz respeito à busca pela morada, que aparece aqui como casas e caixas de morar, totens, chaves, raízes e árvores. Ninguém sabe o que tem dentro das casas e blocos de Pastore. Elas nos lembram que o mistério não pode ser ignorado, esquecido, suprimido, desconsiderado, tampouco desvendado, e que ele se faz presente onde tudo nos é mais familiar. A morada de Pastore é habitada pelo mistério, e ao conhecer suas frestas, portas e janelas, temos uma vontade irresistível de escorregar para dentro: os orifícios e poros são um convite para que caminhemos na beirada. Os contornos de suas figuras delimitam o dentro e o fora, mostram limites, membranas, pele, olho. Ele cria uma brecha na cidade, uma fenda, um portal de passagem para outra realidade que já se dá no aqui e agora. O que nos intriga é o mistério do que está nos interstícios da obra, para além e aquém dela, nos seus buracos e vazamentos. Em algum momento as casas de Bruno foram construídas sobre galhos de árvore. Os galhos assemelham-se a raízes ao contrário, que, paradoxalmente, afastam e aproximam, como se assim sua ligação com o solo ficasse em evidência, destacando, ao mesmo tempo, seu enraizamento e sua distância da terra. Nessas figuras podemos observar o contraste entre materiais orgânicos e vivos, ligados à terra por suas raízes -as árvores; e caixas de morar quadradas e pesadas, feitas de material duro, gelado e artificial. A sensação que esse contraste nos passa é de que os galhos são frágeis demais para sustentar o peso das casas, como se pudessem a qualquer momento sucumbir, mas, incrivelmente, não o fazem. A seguir, algumas moradas gráficas de Pastore: 
Maíra Mendes Clini

As Cores de Pastore: reflexões fenomenológicas sobre o grafite e a arte de viver

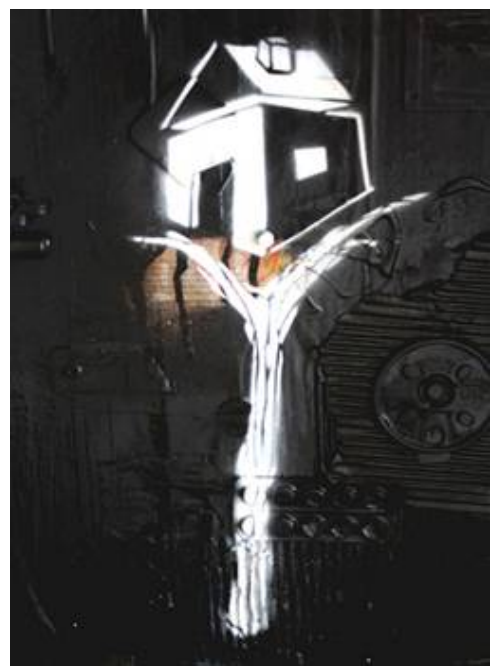

$15 / 12 / 09$

Desapego - o luto do objeto como obra A obra é a vida, a construção de uma morada em si. Spray e stencil sobre textura de collage. Caixa de arte.

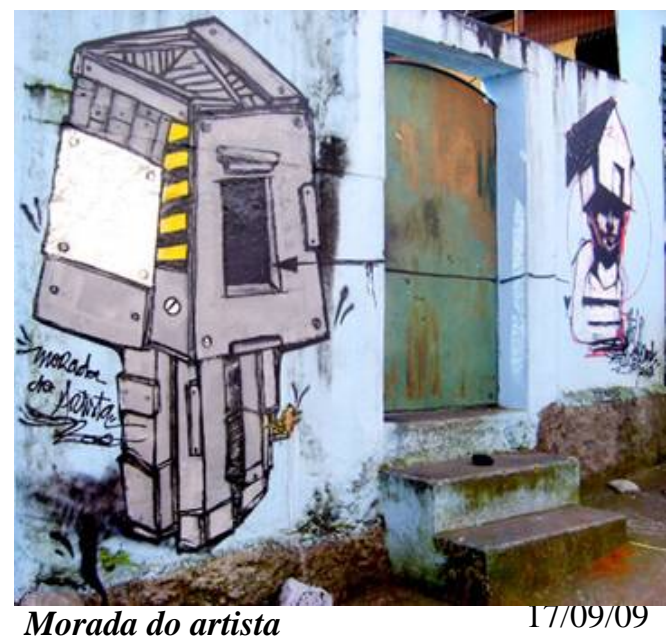

Casa de passarinho, corpo presente.

O artista deve construir sua morada atraindo e construindo coisas, sabendo, tendo a total noção do que constrói ele se auto adquire. Em busca do real.

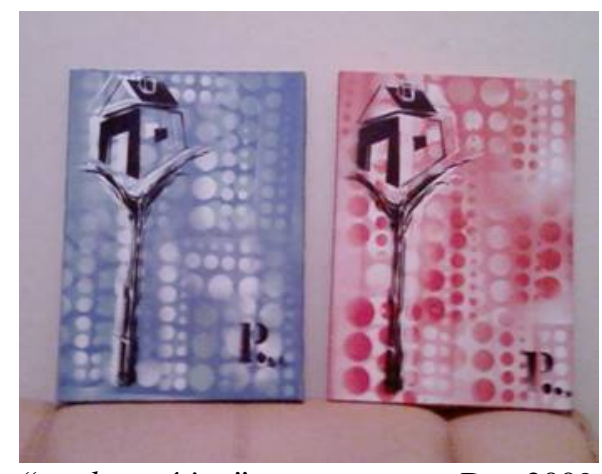

“apelo estético” Dez 2009 


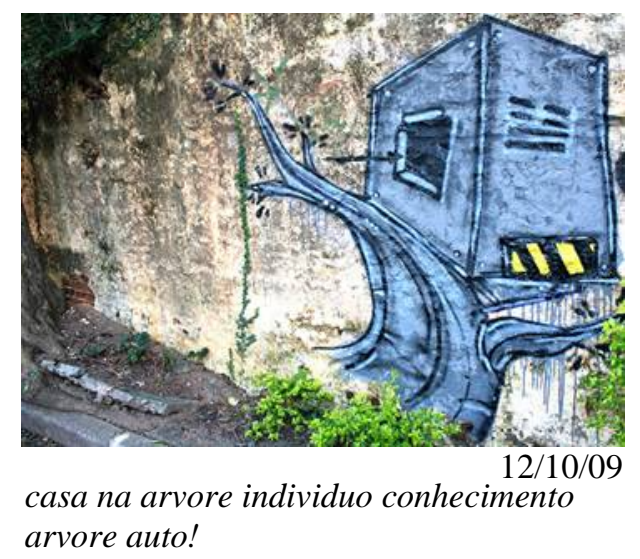

A Morada do artista aponta para a busca de Pastore de se encontrar, de construir paredes sólidas para sua própria casa, chão, teto, janelas e portas que se refiram à sua jornada, onde ele caiba e possa existir. Citando o próprio Bruno Pastore: Tendo a total noção do que constrói ele se auto adquire.

Como ápice do percurso que acompanhamos junto a Pastore, vieram ao nosso encontro a série gráfica dos totens. Eles são casas que apontam para o céu, que guardam em si o enigma da fenda sem escancará-la. São casas cujas janelas encontram-se além de nossos olhos, e suas portas se abrem e se fecham sem que possamos nos dar conta. Os totens de Pastore parecem condensar as imagens de casa, caixas de morar, chaves, árvores e falos, tudo em apenas um símbolo: o totem. Ele nos aponta poder, projeção, remete à vontade de ser alguém. Os totens de Pastore, assim como suas árvores, têm raízes fortes no solo, mas rememoram ininterruptamente a ligação com o céu; e ainda explicitam a tensão entre o orgânico e o artificial. Segundo Pastore, eles registram barreiras encontradas em seu percurso pessoal, que muitas vezes são por ele mesmo criadas; ao mesmo tempo remetem à possibilidade de ensaiar novos saltos, de projetar atravessamentos que o aproximem de seus desejos.

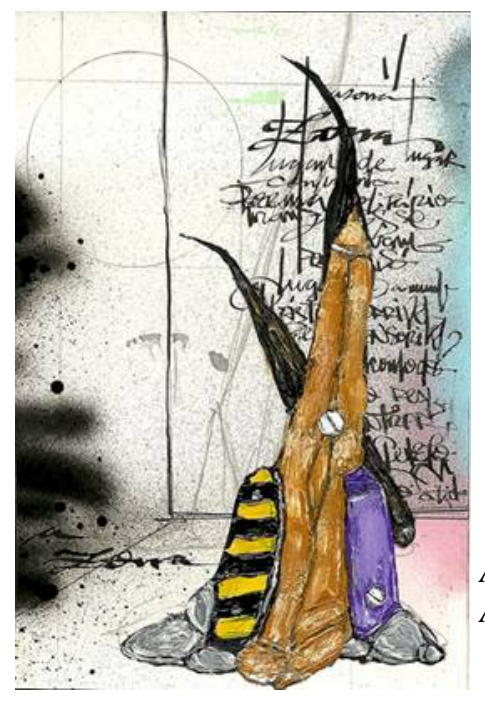

Azona

Acrílica e nanquim bico de pena sobre cartão de esboço

Fevereiro de 2010 
Na obra subseqüente, Pastore crava um olho no meio de um muro chapado, inventando uma brecha que nos leva alhures, forçando uma ruptura que escancara um céu azul e um amplo horizonte. Ele batiza essa obra de Fazer olho (no literalmente), e nos conta que a recriação do olhar existe. Ele fez um olho novo e inusitado no seio de Guarulhos, e com isso provocou que algo fosse enxergado por quem tem olhos. O guarda daquela rua tem olhos, e aqui aparece uma parceria inesperada: ele interage com a pintura de Pastore e a partir disso inicia-se um diálogo. Pastore incorpora os escritos do guarda em sua obra, e valida essa troca, postando-a em seu blog seguida por um texto de sua autoria. A seguir, veremos as etapas da obra:

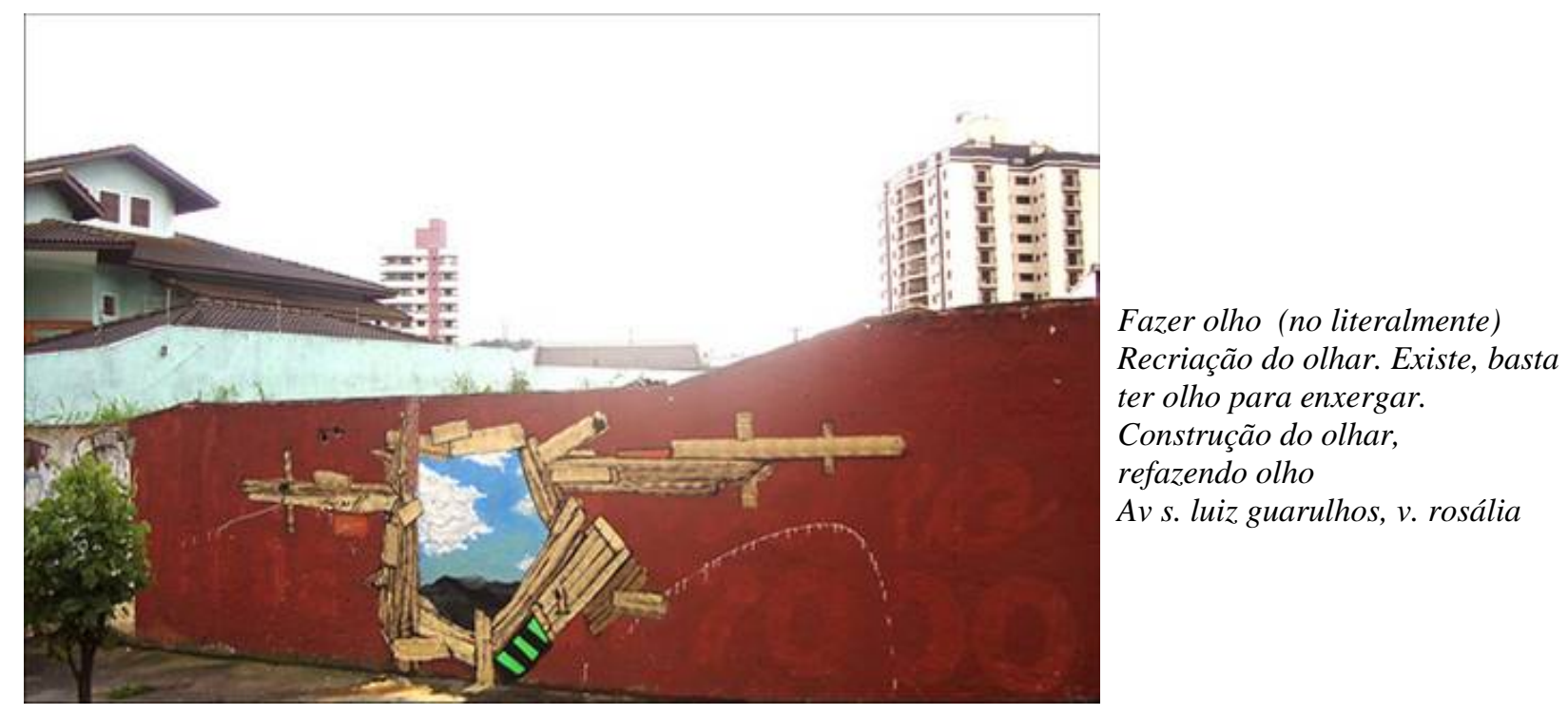

Passando, vi uma intervenção feita no trabalho que fiz há algumas semanas pelo guarita que trabalha ao lado do muro. Durante o processo da pintura, ele disse que meu trabalho era um espectro de depois do terremoto no Chile e o intitulou como "depois do terremoto". Completei dizendo-o, tens razão, depois da tempestade sempre vem a bonança, já que nestas pinturas, digo de uma inversão de perspectiva, reconstruindo o olhar perante as coisas e como elas se apresentam. Ele, um ser de expressão e linguagem, não ia deixar de se dizer em meu trabalho - o trabalho se dilui sendo hoje, mais dele e dos transeuntes do que meu, até por vivência e convivência- e escreveu seu parecer, dizendo mais do trabalho, denunciando o inacabado, abrindo uma lacuna a ser decifrada:

“Depois do terremoto toda raça humana se foi tudo porque não tinha Deus"

O trabalho se afirma, assim como a frase, em várias clivagens.

Realizado numa linguagem atual, na práxis, este trabalho diz 
o mesmo que um herético declarou à Ruysbroeck, mistico de Bruxelas: "Deus nada pode saber, desejar ou fazer sem mim. Com Deus, criei-me e criei todas as coisas, e é a minha mão que sustenta o céu, a terra e todas as criaturas. Sem mim, nada existe".

Diz de uma construção inumana que passa pelo humano e veio a tona por este guarita pensador. Diz deste trabalho, um olhar para as coisas que nos une e que estão ai, sempre estiveram e hoje são esquecidas pela falta de vê-las, por uma descrença maquiada de um "niilismo normal aos dias de hoje".

Digo, contra esta balela contemporânea e de lenta dinamitação de Deus, sobre nossos guardiões (céu, horizonte, mar, pedras, plantas, lagos e arvores) que desde sempre nos sustentaram, espelhando nossas reflexões, nossas quimeras, pensamentos sobre a vida $e$ suas sugestões. "As pessoas caminham pela praia, a praia caminha pelas pessoas", o trabalho segue defendendo os dias de hoje, passando pelo que escreveu o poeta Chacal, dizendo de uma voz em nós, latente nas coisas, como sempre esteve, e cabe ao indivíduo ouvi-la. Tudo em nós depende de nós, é deste resgate que esta construção vos fala, invertendo a frase e pensando seu sentido a partir de um novo olhar:

"Depois do terremoto Deus se foi tudo porque não tinha raça humana".

Para Heidegger, espaço é acontecimento. Nas considerações de Heidegger acerca das esculturas, ele afirma que “torna-se necessário pensar a margem de reciprocidade <das Ineinanderspiel> entre a Arte e o Espaço, a partir da experiência do lugar e da região. A Arte como plasticidade: não como um manuseamento do espaço. A escultura não será um debate com o espaço" (Heidegger, 1969/2009). Tampouco o grafite é um debate com o espaço, mas antes disso, o grafite abre ao redor de si uma região de encontro. Ele presentifica um modo humano de habitar a terra e se relacionar com o mundo e com os outros homens. "Presentificação é a essencialização de um lugar como o lugar que é. Este 'como' é que faz o lugar ser lugar. Lugar é mundo” (MOONSGURGER, 2008, p. 43 grifo da autora).

As obras de arte instalam, erigem e sustentam as relações humanas em seu modo mais fundamental. Elas não são coisas que ocupam espaço, apenas, mas sim convidam a habitação em torno de si. "A escultura seria então uma incorporação de lugares que, abrindo uma região e preservando-a, teriam reunidos à sua volta qualquer coisa de livre que permite a estadia a todas as coisas e habitação ao homem no meio destas." (Heidegger, 1969/2009). Assim também o grafite, completaríamos nós. Independentemente de onde o grafite aconteça, ele abre um espaço de relações em torno de si, ele funda 
uma região de encontro original, "isto quer dizer: desbravar, abrir caminhos inóspitos <die Wildnis freimachen>. Espaçar comporta o livre, o aberto, para um estabelecer e um habitar do homem" (Heidegger, 1969/2009). Grafite é a arte de habitar a cidade, que pode se dar no modo próximo ou distante, pois mesmo a displicência e o desleixo são maneiras do homem instalar espaço.

No modo esquecido, embrutecido e automático de levar a vida é possível que se acabe esquecendo das relações humanas. Bruno Pastore nos lembra, porém, da alteridade que existe no mundo do grafite: desde as relações erigidas em torno do grafite e da arte, até as relações de discípulo e mestre (nas quais ele experimenta ambos os papéis), passando por relações familiares, amorosas, de amizade, de rivalidade e competição, etc. É visível o quanto a alteridade traz o incontrolável na presença do outro, aproxima o imprevisível. Segundo Bruno: Quem puder passar por lá e se tocar por aquilo, ótimo, mas isso você não vai ter como controlar... A presença do outro traz reconhecimento, e ao mesmo tempo, o inesperado. Na rua, Bruno se sente legitimado pelo olhar e interação com os outros. Ao plantar uma obra na rua nunca se saberá ao certo como repercutiu na cidade, nos transeuntes, nos apreciadores e moradores. Porém, é o outro que nos ajuda a solucionar o enigma daquilo que nós mesmos produzimos, que traz à tona o que ainda não foi visto. O contato com as pessoas em geral é que faz Bruno se sentir parte integrante da cidade.

No seu percurso pela cidade, em algum momento Bruno Pastore se viu convocado a retornar à sua casa natal. Para se reencontrar, Bruno retorna às suas origens, volta para a casa onde nasceu e passou sua infância. Os significados guardados ali extrapolam as paredes da casa: espalham-se pelo bairro. Ele quer resgatar peças do quebracabeça que ficaram para trás ao longo de sua vida. Bruno volta à casa natal, retorna às origens para retomá-las e torná-las suas. Passado e presente se encontram coroando as possibilidades de futuro. Aos vinte e quatro anos de idade ele conhece seu pai. Ele reinventa sua profecia de abandono. A raiz paterna pode ser recuperada, e assim a postura de Bruno pode tornar-se completa. Pai de filho homem, filho homem de pai re-conhecido. Vejamos um trecho do relato de Bruno de como foi o reencontro com o pai, e das repercussões que isso teve no modo dele enxergar a si mesmo e a vida:

Eu ficava imaginando como seria o rosto dele. $E$ eu imaginava mais ou menos eu, pois minha mãe sempre falou que eu era parecido com meu pai. $\mathrm{E}$ eu sou muito parecido mesmo com ele. E hoje ele falou, que fez isso não porque duvidava que eu fosse filho dele, foi um jeito dele escapar, pois ele estava enroscado lá numas coisas. Foi muito emocionante, eu não tinha desenhado muito bem ele. Eu desenhava o rosto a partir de mim, e via as cenas, como 
seria, até dava risada, e via as pessoas rindo, também... Ele é um bom pai, assim, ele é um bom pai. Ele é uma pessoa assim, não é nada do que eu esperava, até porque eu não esperava nada... E o meu filho, ele é um atravessador, assim. Ele é o sentido disso tudo, porque se não fosse ele, acho que eu nem ia pensar em pai. Eu ia estar revoltado sem saber, o que é pior ainda, né? Rebelde sem causa. Porque com certeza essas coisas mexeram com o metabolismo familiar. E eu tenho as minhas questões como homem, quem sanaria essas questões de homem? Não tem essa figura masculina presente... Essas coisas... Eu me via muito buscando um pai, buscando um pai, um mestre, buscando um pai artista, um pai... [...] Meu filho é o elo de ligação porque ele sempre foi para mim um passe de entrada, uma legitimação. Porque meu pai poderia se sentir culpado, eu tenho certeza que ele se sente culpado, pois eu percebi no olho dele quando eu troquei a fralda do meu filho na frente dele, ele não quis encarar a cena. Mas encarou. Tudo foi para ele conhecer meu filho, por isso que ele foi atravessador. Para ele não se sentir culpado, olha a fala dele: bom, agora eu vou tirar o tempo perdido com o Pedro. Ou seja, ele vai fazer o que ele não fez comigo, essa coisa de criança, de ver crescer, e é um menino, também. Eu não tenho palavras. $E$ ele [Merleau-Ponty, no texto "A dúvida de Cézanne"] fala muito que o cara era genial pela falta do pai dele, que ele abandonava os quadros como tinha sido abandonado pelo pai. E eu me senti muito nisso. Eu tava num momento de vestir a carapuça e dizer: é isso mesmo, e abandonar... Mas, me vejo muito grato por não ter mais desculpa agora para abandonar mais nada. Eu saí do sintomático. Eu saí do coitado. Não tem mais como, agora. (Pastore, 2010)

Diante do desfecho narrado por Bruno Pastore, quaisquer outras palavras se tornariam excedentes. Finalizamos esse artigo, então, com uma poesia de sua autoria:

De repente toda a minha figura enrubesceu-se e exprimiu o desejo de afundar terra a dentro, de furtar o fogo e encontrar uma língua, trabalhar o horizonte em que outros tombaram e resumir esta quantidade desconhecida

Aqui supero minhas incompetências frente a outras penso se devo continuar nesta partida, só ter sido minhas gagueiras ou ter dado paz nesta vida mas continuo, e este cobre acorda clarim

Pensando o que veio antes, depois de telas visto, perco a inteligência de minhas visões Rebento um salto pelas coisas inauditas 
$(04 / 04 / 10)$

e trago esta pedra para seu tato

\section{Conclusão}

A partir do nosso percurso junto a Bruno Pastore foi possível experienciar a força do entrelaçamento entre arte e vida. A vida de Pastore é a sua obra, assim como sua obra constitui a facticidade de sua vida. Sua obra está em aberto, sua vida em processo, pois cada grafite seu revela etapas de seu percurso, e em sua performance de ser a totalidade de sua vida-obra ainda não se deu. Pastore não produz a partir de sua subjetividade, que seria expressa no ato individual de criação. A obra acontece envolvendo Pastore e toda a comunidade na qual ele vive, evidenciando a duração de uma vida e a marca de uma era.

Ao nos aproximarmos dos fatos da vida de Pastore, e ao nos demorarmos junto à sua obra, somos lançados na contundência da trama entre ambas, e desse lugar já não é mais possível comprovar nenhum dualismo ou cisão entre sujeito e objeto, por exemplo. Cada obra, visitada por nós ao longo desse texto, abre ao redor de si uma região de encontro, como guardiões dos grafites de Pastore convivemos com eles, e ao resguardá-los somos imediatamente remetidos à relação dos homens entre si e com sua cidade. O grafite é parte integrante deste mundo que o sustenta, assim como é fração da face do povo que o cria e guarda. Os grafites trazem consigo e erigem toda a fugacidade da época atual. Em seu movimento de passear entre muros e galerias, explicitam, de um lado, a necessidade de eclosão de movimentos juvenis criativos e subversivos, e, de outro, uma forte tendência mercadológica da sociedade. Grafite é a arte de habitar a cidade, que pode se dar no modo próximo ou distante, pois mesmo a displicência e o desleixo são maneiras do homem instalar espaço.

À arte resta a função restauradora de lembrar-nos que precisamos habitar a terra ao invés de usufruir desta. Ao grafite cabe a função inquisidora de ajudar-nos a resgatar a relação genuína com os espaços públicos, e reinventarmos uma ética do habitar na atual cidade.

\section{Referências}

BEAINI, T. C. A arte como fruto das concepções epocais do ser: reconstrução do enfoque heideggeriano. 1985. $147 \mathrm{f}$. Tese. (Doutorado em Psicologia) - Faculdade de filosofia, letras e ciências humanas, Universidade de São Paulo, 1985.

CAMPOS, M. J. Arte e Verdade. São Paulo: Loyola, 1992. 
CASANOVA, M. A., Heidegger e o acontecimento poético da verdade. In: HADDOCK-LOBO, R. (org). Os filósofos e a arte. Rio de Janeiro: Rocco, 2010. p. 151-180.

Nada a caminho: I mpessoalidade, niilismo e técnica na obra de Martin Heidegger. Rio de Janeiro: Forense Universitária, 2006.

COSTA-MOURA, F. Manifestos de quem não tem o que dizer: adolescentes contemporâneos e os graffiti de rua. Estilos Clínicos, São Paulo, v. 10, n. 18, p. 116-130, 2005.

DUARTE, A.; Heidegger e a obra de arte como acontecimento historial-político. Artefilosofia, Ouro Preto, n. 5, v. 1, p.2 3-33, julho, 2008.

ESTRELLA, C., A visualidade de São Paulo e o vocabulário popular do graffiti - a poética dos gêmeos. São Paulo: Editora Instituto de Psicologia da Universidade de São Paulo. Núcleo Interdisciplinar do Imaginário e Memória. Laboratório de Estudos do Imaginário: 2006.

FIGUEIREDO, L.C.; Escutar, recordar, dizer: encontros heideggerianos com a clínica psicanalítica. São Paulo: EDUC/Escuta, 1994.

FURTADO, J. R; ZANELLA, A. V.; Artes visuais na cidade: relações estéticas e constituição dos sujeitos. Psicologia em Revista, Belo Horizonte, v.13, n.2, p.309-324, 2007.

GONÇALVES FILHO, J. M.. Cultura e Formação: notas marginais. In: FRAYZE-PEREIRA, J. A., PATTO, M. H. S; Pensamento Cruel. Humanidades e Ciências Humanas: há lugar para a psicologia? São Paulo: Casa do Psicólogo, 2007, p.187 -204.

. Humilhação social: humilhação política. In: SOUZA, B.P.S.

(org) Orientação à queixa escolar. São Paulo: Casa do Psicólogo, 2007, p. 187-219.

Humilhação social - um problema político em psicologia.

Psicologia USP, São Paulo, v. 9, n. 2, 1998. Disponível em <http://www.scielo.br/scielo.php?script=sci_arttext\&pid=S01036564 1998000200002\&lng=pt\&nrm=iso>. acesso em 18 fev. 2010. doi: 10.1590/S0103-65641998000200002.

GONÇALVES, F. N.; ESTRELLA, C. Comunicação, arte e invasões artísticas na cidade. LOGOS 26: comunicação e conflitos urbanos. Ano 14, 2007. Disponível em: <http://www.logos.uerj.br/PDFS/26/07_FERNANDO_CHARBELLY.pdf $>$. Acesso em 12 de abril de 2009.

GUZZONI, U.; A relação entre o espaço e a arte no Heidegger tardio. Artefilosofia, Ouro Preto, n.5,v.1, p.48-60, julho,2008.

HAAR, M. A.; Obra de Arte: ensaio sobre a ontologia das obras. Rio de Janeiro: Difel, 2007.

HEIDEGGER, M. (1969). A arte e o espaço. Traduzido por José Carlos Cardoso. Disponível em: 
<http://acotedelaplaque.blogs.sapo.pt/47443.html>. Acesso em 05 de outubro de 2010.

A coisa. In: Ensaios e Conferências. Petrópolis: Ed. Vozes, 2008a , p. $143-164$.

. (1936). A Origem da Obra de Arte. Tradução de Irene Borges-Duarte e Filipa Pedroso. In: Caminhos de Floresta. Lisboa: Fundação Calouste Gulbenkian, 1998.

. (1936). A Origem da Obra de Arte. Tradução de Laura de Borba Moosburger. Curitiba: Universidade Federal do Paraná, 2007.

A questão da técnica In:

Petrópolis: Ed. Vozes, 2008b. p.11-38.

. Ensaios e Conferências.

Construir, Habitar, Pensar. In:

Ensaios e

Conferências. Petrópolis: Ed. Vozes, 2008c, p.125-141.

(1935). Hinos de Hölderlin. Lisboa: Instituto Piaget, 2004.

“... poeticamente o homem habita...; In:

Conferências. Petrópolis: Ed. Vozes, 2008 d, p.165-18

Ensaios e

(1964) Observações sobre arte - escultura - espaço.

Artefilosofia, Ouro Preto, n. 5, v.1, p. 15-22, julho, 2008e.

(1938) O tempo da imagem no mundo. In:

Caminhos de Floresta. Lisboa: Fundação Calouste Gulbenkian, 1998.

Cultural. 1989.

Que é metafísica. Col. Os pensadores. São Paulo. Abril

Ser e Tempo (1926). Volume I. Rio de Janeiro: Editora Vozes, São Paulo: Universidade São Francisco, 2004.

JARDIM, L. Articulação da afinação e a arte para Martin Heidegger. "Existência e Arte"- Revista Eletrônica do Grupo PET - Ciências Humanas, Estética e Artes da Universidade Federal de São J oão Del-Rei - Ano III - Número III. P. janeiro a dezembro de 2007.

Disponível em: <http://www.ufsj.edu.br/portalrepositorio/File/ existenciaearte/Edicoes/3_Edicao/Luis\% 20E\% 20J ardi m\%20FI LOSOFIA\%20ok. pdf >. Acesso em 20 maio 2013.

MERLEAU-PONTY, M. A dúvida de Cézanne. In: O Olho e o Espírito: seguido de A linguagem indireta e as vozes do silêncio e A dúvida de Cézanne. São Paulo: Cosac e Naif, 2004, p. 121-142.

MOOSBURGER, L. Mundo, terra e "não-encobrimento" em A origem da obra de arte. Artefilosofia, Ouro Preto, n.5, v.1, p.35-47, julho, 2008.

NUNES, B. Hermenêutica e poesia: o pensamento poético. Belo Horizonte: Editora UFMG, 2007.

PATTO, M. S.; FRAYZE-PEREIRA, J. A. (Orgs); Pensamento cruel Humanidades e ciências humanas: há lugar para a psicologia? São Paulo: Casa do Psicólogo, 2007.

PESSANHA, J. G. Heidegger e a velha: falar e não falar... In:

Instabilidade perpétua. São Paulo: Ateliê Editorial, 2009, p. $\overline{7} \overline{7}-\overline{8} \overline{6}$. 
SARAMAGO, L. Sobre A arte e o espaço, de Martin Heidegger. Artefilosofia, Ouro Preto, n. 5, v.1, p.61-72, julho,2008.

SCANDIUCCI, G. Cultura hip hop: um lugar psíquico para a juventude negro-descendente das periferias de São Paulo. I maginário, São Paulo, v.12, n.12, p. 225-249,2006.

. O lugar do Hip Hop em São Paulo e os desenhos grafitados como marcas das periferias. In: Sérgio Poato: Maria de Lourdes Beldi de Alcântara. (Org.). Graffiti na cidade de São Paulo e sua vertente no Brasil. São Paulo: DP, p.71-73, 2006.

SILVA, I. J. O. Graffiti - Criptografias do desejo. Imaginário, São Paulo, v.1 2, n. 12, p. 39-45, 2006.

SILVA, R. L. Escutando a adolescência nas grandes cidades através do grafite. Psicologia: Ciência e Profissão, v. 24, n. 4, p. 2-11, 2004.

SILVA, R. L.; SILVA, R. N. Paradigma preventivo e lógica identitária nas abordagens sobre o Hip Hop. Fractal, Revista de Psicologia. Rio de Janeiro, v. 20, n. 1, Junho, p. 135- 148, 2008.

\section{Endereço para correspondência Maíra Mendes Clini}

Av. Prof. Mello Moraes, 1721. CEP 05508-030. Universidade de São, Cidade Universitária. São Paulo - SP.

Endereço eletrônico: mairamc@yahoo.com

Recebido em: 21/03/2012

Reformulado em: 23/05/2013

Aceito para publicação em: 28/05/2013

Acompanhamento do processo editorial: Ana Maria Lopez Calvo de Feijoo

\section{Notas}

*Doutoranda em psicologia social pela USP. Mestre em psicologia da arte pela USP. Graduada em psicologia pela PUC-SP. Professora de psicologia da Universidade FMU, São Paulo, Brasil.

${ }^{1}$ Utilizarei a grafia do termo grafite em português, apesar de constar na literatura, muitas vezes, sua versão em inglês: graffiti, o que poderia diferenciar o termo que se refere a escrituras em paredes do termo que designa a substância mineral. Como neste trabalho está claro a qual grafite me refiro, optei por privilegiar o termo na língua portuguesa.

${ }^{2}$ Para conhecer detalhadamente o percurso de Bruno Pastore, e mesmo ter acesso à sua obra, consultar:

<http:// www.teses.usp.br/teses/disponiveis/47/47134/tde-09022011-

$105236 /$ fr.php>.

3 Continuaremos utilizando a palavra homem para facilitar a leitura, porém, Heidegger discorda veementemente dessa denominação, utilizando a palavra dasein, que pode traduzida do alemão por ser-aí, assim contrapondo-se a toda tradição metafísica que concebe o homem como sujeito, pessoa, ego ou psique.

4 As legendas das figuras, assim como os textos e poemas do artista, são reproduções literais das postagens de Bruno Pastore em seus blogs, a autora não as modificou absolutamente. Os trechos de relatos de Bruno Pastore aparecerão com recuo de $4 \mathrm{~cm}$ da margem, e em itálico.

${ }^{5}$ Sites e blogs de Bruno Pastore: <http://www.fotolog.com.br/paaast/> ; 
As Cores de Pastore: reflexões fenomenológicas sobre o grafite e a arte de viver

<http://literalmentepastore. blogspot.com>; $<$ http://www.flickr.com/photos/pastlore>; <http://www.flickr.com/photos/pastore4life>; $<$ http://pastoretrezeleguas. blogspot.com> 